\title{
Peertechz
}

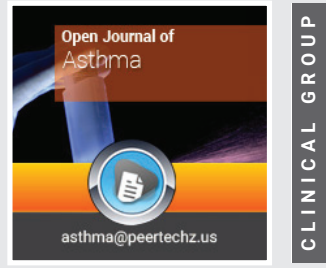

\section{Eating rabbit meat and blood cannot cure asthma}

\section{Entezar Mehrabi Nasab ${ }^{1}$ and Seyyed Shamsadin Athari ${ }^{2 *}$}

${ }^{1}$ Cardiologist, Tehran Heart Center, Tehran University of Medical Sciences, Tehran, Iran

${ }^{2}$ Immunologist, Department of Immunology, School of Medicine, Zanjan University of Medical

Sciences, Zanjan, Iran

Received: 28 June, 2021

Accepted: 23 August, 2021

Published: 24 August, 2021

*Corresponding author: Seyyed Shamsadin Athari, Department of Immunology, School of Medicine, Zanjan University of Medical Sciences, Zanjan, Iran, Email: SS.Athari@gmail.com, SS.Athari@zums.ac.ir https://www.peertechzpublications.com

\section{Check for updates}

Asthma is a complicated chronic airway disease that characterized by structural and functional changes responsible for airway hyperresponsiveness and usually reversible airway obstruction. Allergic asthma is widely triggered by an immune-inflammatory response driven by Th2 lymphocytes and these cells contribute to the pathogenesis of asthma, thus worsening its severity. Airway hyperresponsiveness, goblet cell hyperplasia, mucus hypersecretion and eosinophilic inflammation are orchestrated by Th2 cytokines such as IL4, 5 and 13. In the allergic asthma, these exacerbations can be caused by allergens. Its prevalence is continuously increasing worldwide. In some countries, asthmatic subjects who are affected by the severe subtypes of the disease, having a poor quality of life and patients with uncontrolled asthma exhibit have a high risk of morbidity and mortality. Therefore, in low income countries, patients with severe asthma are not given enough health care services, and they use the local recommendations according to socio-economic reasons [1]
Inside of developed drugs, traditional medicines are used to control and manage of asthma. According to the unofficial reports, in some area of some countries such as Iran, local people believe that eating rabbit meat and blood can completely cure asthma. According to recent searches, there is no evidence that show rabbit meat or blood have benefit effect in cure or control of asthma (Figure 1). This treatment is wrong and unscientific protocol.

There are many similar treatments in most countries. In Indian, thousands of people with asthma travel to Hyderabad where the medicine is delivered free to the asthmatic patient in the mouth of a live fish. The hedgehog's meat is eaten by some asthmatic patient to completely cure of asthma attack [2,3]. Wild animal meat allergy and zoonoses infectious diseases transmitting are other harmful result of these treatments and are dangerous approach in public health. Inadequate fund for prolonged treatment, inadequate health care facilities,

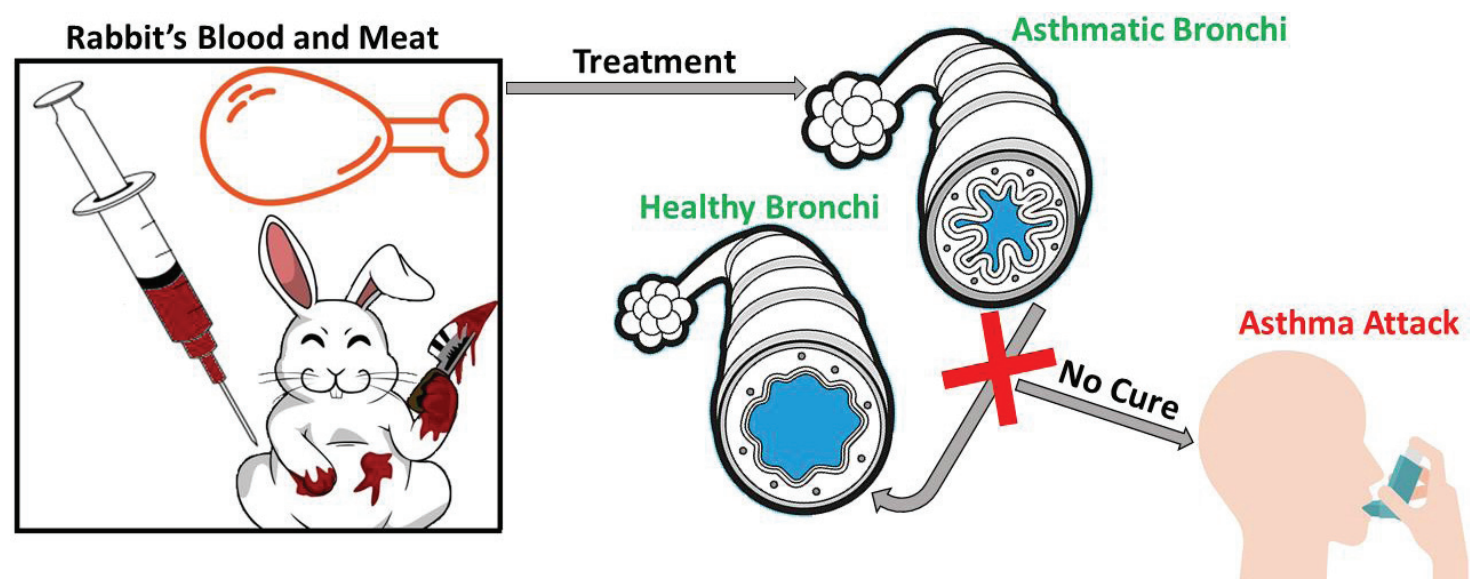

Figure 1: Some local people believe that eating rabbit meat or blood can cure asthma. But there isn't evidence that approve rabbit meat or blood can cure asthma and this treatment has no benefit effect in control of asthma. 
poor medical infrastructure, insufficient para-medical staff, high cost of drugs, Poor level of literacy, poverty, distrust for doctors, fear of social stigma, lure for homeopathy and wrong traditional treatment have increased these behaviors and encouraged local peoples for self-treatment of asthma $[4,5]$. Therefore, we have duty to increase people's knowledges, prevent these unscientific treatments and similar methods, keep safe animal and improve animal rights ethics, stop animal hunting, and also, lead asthmatic patients to receive correct treatment.

\section{References}

1. Athari SS, Athari SM (2014) The importance of eosinophil, platelet and dendritic cell in asthma. Asian Pac J Trop Dis 4: 41-47. Link: https://bit.ly/2WjTeMf
2. Kumar S (2004) Traditional Indian remedy for asthma challenged in court BMJ 328: 1457. Link: https://bit.ly/3B6ip42

3. Kumar M, Athari SS (2014) Serious Warning about Eating Hedgehog Meat for Treatment of Asthma. Journal of Food Quality and Hazards Control 1: 125. Link: https://bit.ly/3klvqQN

4. Webb JY (1971) Louisiana voodoo and superstitions related to health. HSMHA Health Rep 86: 291-301. Link: https://bit.ly/3mnjFf1

5. Gupta SK, Sen Mazumdar K, Gupta S, Sen Mazumdar A, Gupta S (1998) Patient education programme in bronchial asthma in India: why, how, what and where to communicate? Indian J Chest Dis Allied Sci 40: 117-124. Link: https://bit.ly/3j9u2kP

\section{Discover a bigger Impact and Visibility of your article publication with}

Peertechz Publications

\section{Highlights}

* Signatory publisher of ORCID

- Signatory Publisher of DORA (San Francisco Declaration on Research Assessment)

* Articles archived in worlds' renowned service providers such as Portico, CNKI, AGRIS, TDNet, Base (Bielefeld University Library), CrossRef, Scilit, J-Gate etc.

* Journals indexed in ICMJE, SHERPA/ROMEO, Google Scholar etc.

* OAI-PMH (Open Archives Initiative Protocol for Metadata Harvesting)

* Dedicated Editorial Board for every journal

- Accurate and rapid peer-review process

* Increased citations of published articles through promotions

* Reduced timeline for article publication

Submit your articles and experience a new surge in publication services (https://www.peertechz.com/submission).

Peertechz journals wishes everlasting success in your every endeavours.

Copyright: ( 2021 Nasab EM, et al. This is an open-access article distributed under the terms of the Creative Commons Attribution License, which permits unrestricted use, distribution, and reproduction in any medium, provided the original author and source are credited. 